\title{
Tolerance of mung bean to postemergence herbicides
}

\author{
Nader Soltani", Christy Shropshire, Peter H. Sikkema \\ University of Guelph Ridgetown Campus, Ridgetown, Canada; ${ }^{*}$ Corresponding Author: soltanin@,uoguelph.ca \\ Received 21 July 2013; revised 24 August 2013; accepted 20 September 2013 \\ Copyright (C) 2013 Nader Soltani et al. This is an open access article distributed under the Creative Commons Attribution License, \\ which permits unrestricted use, distribution, and reproduction in any medium, provided the original work is properly cited.
}

\section{ABSTRACT}

There are a limited number of postemergence (POST) herbicides available for weed management in mung bean production in Ontario. Five field studies were conducted in 2010, 2011 and 2012 near Exeter, Ontario and in 2011 and 2012 near Ridgetown, Ontario to determine the tolerance of mung bean to fomesafen, bentazon, bentazon + fomesafen and halosulfuron applied POST at the $1 X$ and $2 X$ proposed manufacturer's recommended rate. Bentazon caused $5 \%-29 \%$, $4 \%-31 \%$, and $2 \%-18 \%$ injury, fomesafen caused $3 \%-17 \%, 1 \%-7 \%$, and $0 \%-6 \%$ injury, bentazon + fomesafen caused $6 \%-40 \%, 4 \%-37 \%$, and $1 \%-20 \%$ injury, and halosulfuron caused $13 \%-65 \%, 8 \%-75 \%$, and $5 \%-47 \%$ injury in mung bean at 1, 2, and 4 weeks after treatment (WAT), respectively. At Exeter, fomesafen had no adverse effect on height of mung bean but bentazon, bentazon + fomesafen and halosulfuron decreased mung bean height as much as $5 \%$ compared to the untreated control. At Ridgetown, there was no decrease in mung bean height due to the herbicides applied. Fomesafen had no adverse effect on shoot dry weight of mung bean but bentazon, bentazon + fomesafen and halosulfuron decreased shoot dry weight of mung beans as much as $43 \%, 47 \%$, and $57 \%$, respectively. Fomesafen, bentazon, bentazon + fomesafen and halosulfuron had no adverse effect on the seed moisture content and seed yield of mung bean with the exception of halosulfuron applied POST at $70 \mathrm{~g}_{\text {ai }} \mathrm{ha}^{-1}$ which increased seed moisture content $0.4 \%$ at Exeter and $1.4 \%$ at Ridgetown and decreased yield $16 \%$ at Exeter compared to the untreated control. Based on these results, there is not an adequate margin of crop safety for bentazon, bentazon + fomesafen and halosulfuron applied POST in mung bean. However, there is potential for fomesafen applied POST at the proposed manufacturer's rate of $240 \mathrm{~g}_{\text {ai }} \mathrm{ha}^{-1}$ in mung bean production.

Keywords: Height; Injury; Seed Moisture Content; Shoot Dry Weight; Yield

\section{INTRODUCTION}

Mung bean (Vigna radiata (L.) R. Wilczek) is a specialty crop grown in Ontario for domestic use as well as export to Japan [1]. There is also potential for exporting mung beans to United States as currently it imports nearly $75 \%$ of its need from China [1]. Weed management in mung beans is one of the main production concerns for growers as mung bean, similar to other dry beans, has short stature and slow early growth and therefore is not a competitive crop with weeds. Weed interference in dry bean can reduce seed yield as much as $83 \%$ [2-4] and can interfere with harvest efficiency and may cause staining and reduce seed quality [5-7]. There is limited number of postemergence (POST) herbicides available for mung bean production in Ontario [8]. More research is needed to identify POST herbicides that provide broadleaved weed control in mung beans.

Bentazon is a benzothiadiazole herbicide that controls broadleaved weeds including common lambsquarters (Chenopodium album), velvetleaf (Abutilon theophrasti), ladysthumb (Polygonum persicaria), wild mustard (Sinapis arvensis), purslane (Portulaca oleracea), wild radish ( $R a-$ phanus raphanistrum), hairy galinsoga (Galinsoga ciliata), jimsonweed (Datura stramonium), cocklebur (Xanthium strumarium), shepherdspurse (Capsella bursapastoris) and common chickweed (Stellaria media) including acetolactate synthase and triazine-resistant biotypes $[8$, 9].

Fomesafen is a diphenyl ether herbicide that controls broadleaved weeds including Sinapis arvensis, redroot 
pigweed (Amaranthus retroflexus), common ragweed (Ambrosia artemisiifolia), Polygonum persicaria, Xanthium strumarium and Solanum spp.) including acetolactate synthase and triazine-resistant biotypes [8,9]. Fomesafen in tank mix combination with bentazon provides improved control of broadleaved weeds such as Amaranthus, Ambrosia, Solanum species and Polygonum convolvulus $[8,9]$.

Halosulfuron is a sulfonylurea herbicide that controls broadleaved weeds including Chenopodium album, Amaranthus retroflexus, Abutilon theophrasti, Polygonum persicaria, Xanthium strumarium, Sinapis arvensis, and yellow nutsedge (Cyperus esculentus), including triazine resistant biotypes [9]. Halosulfuron is active at low doses, possesses low mammalian toxicity, is relatively immobile in the soil and degrades rapidly, so it has little potential to contaminate groundwater and the environment [9].

There is little information on sensitivity of mung bean to fomesafen, bentazon, bentazon + fomesafen and halosulfuron applied POST. Fomesafen, bentazon, bentazon + fomesafen and halosulfuron applied POST can provide Ontario mung bean growers with new herbicides options that provide control of specific broad leaved weeds.

The objective of this research was to determine the tolerance of mung bean to fomesafen, bentazon, bentazon + fomesafen and halosulfuron applied POST at the $1 \mathrm{X}$ and $2 \mathrm{X}$ proposed manufacturer's recommended rate.

\section{MATERIALS AND METHODS}

Field studies were conducted in 2010, 2011, and 2012 at the Huron Research Station, Exeter, Ontario, Canada and in 2011 and 2012 at the University of Guelph Ridgetown Campus, Ridgetown, Ontario, Canada. The soil at Exeter was a Brookston clay loam (Orthic Humic Gleysol, mixed, mesic, and poorly drained) and the soil at Ridgetown was a Wattford (Grey-Brown Brunisolic, mixed, mesic, sandy, and imperfectly drained)-Brady (Gleyed Brunisolic Grey-Brown Luvisol, mixed, mesic, sandy, and imperfectly drained) sandy loam. Seedbed preparation at all sites consisted of fall mold board plowing followed by two passes with a field cultivator with rolling basket harrows in the spring.

The experiments were established as a randomized complete block design (RCBD) with four replications. Treatments included an untreated control, bentazon (1080 and $2160 \mathrm{~g}_{\text {ai }} \mathrm{ha}^{-1}$ ), fomesafen (240 and $480 \mathrm{~g}$ ai ha ${ }^{-1}$ ), bentazon + fomesafen $(840+140$ and $1680+280 \mathrm{~g}$ ai $\mathrm{ha}^{-1}$ ), and halosulfuron (35 and $70 \mathrm{~g}$ ai ha ${ }^{-1}$ ) applied POST. Plots were $3 \mathrm{~m}$ wide (4 rows spaced $0.75 \mathrm{~m}$ apart) and $10 \mathrm{~m}$ long at Exeter and $8 \mathrm{~m}$ long at Ridgetown. Mung beans ("Harosprout") were planted 3 - $4 \mathrm{~cm}$ deep at the rate of 220,000 seed $^{-1}$ in late May to early June of each year.

Herbicide applications were made to 2 - 3 trifoliate leaf mung beans with a $\mathrm{CO}_{2}$-pressurized backpack sprayer calibrated to deliver $200 \mathrm{~L} \mathrm{ha}^{-1}$ of spray solution at a pressure of 200/240 kPa using low drift nozzles (ULD12002, Spraying Systems Co., P.O. Box 7900. Wheaton, IL 60188). The boom was $2.5 \mathrm{~m}$ wide with six nozzles spaced $0.5 \mathrm{~m}$ apart. Plots were maintained weed free by cultivation and hand hoeing as required to eliminate the confounding effect of weed interference.

Mung bean injury was visually estimated on a scale of 0 (no injury) to $100 \%$ (complete plant death) at 1, 2 and 4 weeks after treatment application (WAT). Bean shoot dry weight was determined 2 WAT by cutting plants at the soil surface from $1 \mathrm{~m}$ of row per plot. Plants were dried at $60 \mathrm{C}$ to constant moisture and then weighed. Mung bean height was measured for 10 plants in each plot 5 WAT and averaged. Mung bean was considered mature when $90 \%$ of the pods in the untreated control had turned from green to a golden colour. Beans were harvested from each plot with a small plot combine, weight and seed moisture content were recorded, and seed yields were adjusted to $13 \%$ moisture.

Data were analyzed as an RCBD using PROC MIXED in SAS 9.2. Herbicide treatment was considered a fixed effect, while environment (year-location combinations), the interaction between environment and herbicide treatment, and replicate nested within environment were considered random effects. Significance of the fixed effect was tested using F-test and random effects were tested using a Z-test of the variance estimate. Environments were combined for a given variable if the environment by herbicide treatment interaction was not significant. The UNIVARIATE procedure was used to test data for normality and homogeneity of variance. For all injury ratings, the untreated check (assigned a value of zero) was excluded from the analysis. However, all values were compared independently to zero to evaluate treatment differences with the untreated control. To satisfy the assumptions of the variance analyses, moisture was log transformed (Exeter only), and injury 1, 2 and 4 WAT as well as shoot dry weight were square root transformed. Treatment comparisons were made using Fisher's Protected LSD at a level of $\mathrm{P}<0.05$. Data compared on the transformed scale were converted back to the original scale for presentation of results.

\section{RESULTS AND DISCUSSION}

Analysis of variance indicated that Environment by treatment interaction was significant for all variables except shoot dry weight. Therefore, data for Ridgetown and Exeter are presented separately for all variables except shoot dry weight (Tables 1 and 2). 
Table 1. Percent injury 1, 2 and 4 WAT in mung bean treated with various POST herbicides at Exeter (2010-2012) and Ridgetown, ON (2011-2012). Means followed by the same letter within a column are not significantly different according to Fisher's Protected LSD at $\mathrm{P}<0.05^{1}$.

\begin{tabular}{|c|c|c|c|c|c|c|c|c|c|c|c|c|c|}
\hline \multirow[b]{3}{*}{ Treatment } & \multirow[b]{3}{*}{ Rate } & \multicolumn{12}{|c|}{ Injury } \\
\hline & & \multicolumn{4}{|c|}{$1 \mathrm{WAT}$} & \multicolumn{4}{|c|}{2 WAT } & \multicolumn{4}{|c|}{4 WAT } \\
\hline & & \multicolumn{2}{|c|}{ Exeter } & \multicolumn{2}{|c|}{ Ridgetown } & \multicolumn{2}{|c|}{ Exeter } & \multicolumn{2}{|c|}{ Ridgetown } & \multicolumn{2}{|c|}{ Exeter } & \multicolumn{2}{|c|}{ Ridgetown } \\
\hline & $\mathrm{g}$ ai ha ${ }^{-1}$ & \multicolumn{12}{|c|}{$\%$} \\
\hline Untreated & & 0 & $\mathrm{a}$ & 0 & & 0 & $\mathrm{a}$ & 0 & A & 0 & $\mathrm{a}$ & 0 & $\mathrm{a}$ \\
\hline Bentazon & 1080 & 5 & $\mathrm{~b}$ & 16 & $a b$ & 4 & $\mathrm{~cd}$ & 20 & $\mathrm{C}$ & 2 & $\mathrm{bc}$ & 9 & bcd \\
\hline Bentazon & 2160 & 6 & $\mathrm{~b}$ & 29 & $\mathrm{bc}$ & 6 & de & 31 & $\mathrm{Cd}$ & 3 & $\mathrm{~cd}$ & 18 & de \\
\hline Fomesafen $^{2}$ & 240 & 3 & $\mathrm{~b}$ & 10 & $\mathrm{a}$ & 1 & $\mathrm{~b}$ & 4 & $\mathrm{Ab}$ & 0 & $\mathrm{a}$ & 4 & $\mathrm{~b}$ \\
\hline Fomesafen $^{3}$ & 480 & 5 & $\mathrm{~b}$ & 17 & $\mathrm{ab}$ & 2 & $\mathrm{bc}$ & 7 & $\mathrm{~B}$ & 0 & $\mathrm{a}$ & 6 & $\mathrm{bc}$ \\
\hline Bentazon + fomesafen & $840+140$ & 6 & $\mathrm{~b}$ & 25 & $\mathrm{bc}$ & 4 & $\mathrm{~cd}$ & 28 & $\mathrm{~cd}$ & 1 & $\mathrm{~b}$ & 16 & $\mathrm{~cd}$ \\
\hline Bentazon + fomesafen & $1680+280$ & 8 & $\mathrm{bc}$ & 40 & $\mathrm{~cd}$ & 7 & de & 37 & $\mathrm{~cd}$ & 2 & $\mathrm{bc}$ & 20 & de \\
\hline Halosulfuron $^{4}$ & 35 & 13 & $\mathrm{c}$ & 53 & $\mathrm{~d}$ & 8 & e & 50 & de & 5 & $\mathrm{~d}$ & 31 & ef \\
\hline Halosulfuron $^{5}$ & 70 & 22 & $\mathrm{~d}$ & 65 & $\mathrm{~d}$ & 16 & $f$ & 75 & $\mathrm{e}$ & 9 & $\mathrm{e}$ & 47 & $\mathrm{f}$ \\
\hline SE & & & & & & & & & & & & & \\
\hline
\end{tabular}

${ }^{1}$ Abbreviations: WAT, week after herbicide application; POST, postemergence. ${ }^{2}$ Mineral oil $/$ surfactant blend added at $0.5 \%$ v/v. ${ }^{3}$ Mineral oil/surfactant blend added at $1.0 \% \mathrm{v} / \mathrm{v}$. ${ }^{4}$ Non-ionic surfactant added at $0.25 \% \mathrm{v} / \mathrm{v}$. ${ }^{5}$ Non-ionic surfactant added at $0.5 \% \mathrm{v} / \mathrm{v}$.

Table 2. Shoot dry weight, height, seed moisture content at harvest and yield for mung bean treated with various postemergence herbicides at Exeter (2010-2012) and Ridgetown, ON (2011-2012). Means followed by the same letter within a column are not significantly different according to Fisher's Protected LSD at $\mathrm{P}<0.05^{1}$.

\begin{tabular}{|c|c|c|c|c|c|c|c|c|c|c|c|c|c|c|c|}
\hline \multirow[b]{2}{*}{ Treatment } & \multirow[b]{2}{*}{ Rate } & \multirow{2}{*}{\multicolumn{2}{|c|}{ Dry weight }} & \multicolumn{4}{|c|}{ Height } & \multicolumn{4}{|c|}{ Seed Moisture } & \multicolumn{4}{|c|}{ Yield } \\
\hline & & & & & xeter & & own & Exe & & Ridg & own & Exe & & Ridg & own \\
\hline & g ai ha ${ }^{-1}$ & \multicolumn{2}{|c|}{$\mathrm{g}$} & \multicolumn{4}{|c|}{$\mathrm{cm}$} & \multicolumn{4}{|c|}{$\%$} & \multicolumn{4}{|c|}{$\mathrm{tha}^{-1}$} \\
\hline Untreated & & 58 & $\mathrm{a}$ & 59 & $\mathrm{ab}$ & 85 & $\mathrm{a}$ & 12.1 & $\mathrm{ab}$ & 12.9 & $\mathrm{a}$ & 1.30 & $\mathrm{a}$ & 2.26 & $\mathrm{a}$ \\
\hline Bentazon & 1080 & 35 & $\mathrm{c}$ & 58 & $\mathrm{bc}$ & 87 & $\mathrm{a}$ & 12.2 & $\mathrm{ab}$ & 13.4 & $a b$ & 1.28 & $\mathrm{a}$ & 2.43 & $\mathrm{a}$ \\
\hline Bentazon & 2160 & 33 & $\mathrm{~cd}$ & 56 & $\mathrm{c}$ & 86 & $\mathrm{a}$ & 12.2 & $\mathrm{bc}$ & 13.6 & $a b c$ & 1.26 & $\mathrm{a}$ & 2.33 & $\mathrm{a}$ \\
\hline Fomesafen ${ }^{2}$ & 240 & 54 & $\mathrm{a}$ & 60 & $\mathrm{a}$ & 88 & $\mathrm{a}$ & 12.1 & $\mathrm{ab}$ & 12.9 & $a b$ & 1.35 & $\mathrm{a}$ & 2.49 & $\mathrm{a}$ \\
\hline Fomesafen ${ }^{3}$ & 480 & 48 & $\mathrm{ab}$ & 59 & $\mathrm{ab}$ & 86 & $\mathrm{a}$ & 12.0 & $\mathrm{a}$ & 13.0 & $a b$ & 1.32 & $\mathrm{a}$ & 2.32 & $\mathrm{a}$ \\
\hline Bentazon + fomesafen & $840+140$ & 38 & $\mathrm{bc}$ & 56 & $\mathrm{c}$ & 87 & $\mathrm{a}$ & 12.1 & $\mathrm{ab}$ & 13.3 & $a b$ & 1.25 & $\mathrm{a}$ & 2.39 & $\mathrm{a}$ \\
\hline Bentazon + fomesafen & $1680+280$ & 31 & $\mathrm{~cd}$ & 58 & $\mathrm{bc}$ & 85 & $\mathrm{a}$ & 12.2 & $\mathrm{ab}$ & 13.5 & $a b$ & 1.29 & $\mathrm{a}$ & 2.36 & $\mathrm{a}$ \\
\hline Halosulfuron ${ }^{4}$ & 35 & 31 & $\mathrm{~cd}$ & 57 & $\mathrm{bc}$ & 74 & $\mathrm{a}$ & 12.1 & $\mathrm{ab}$ & 13.7 & $\mathrm{bc}$ & 1.26 & $\mathrm{a}$ & 2.43 & $\mathrm{a}$ \\
\hline Halosulfuron $^{5}$ & 70 & 25 & $\mathrm{~d}$ & 56 & $\mathrm{c}$ & 73 & a & 12.5 & $\mathrm{c}$ & 14.3 & $\mathrm{c}$ & 1.09 & $\mathrm{~b}$ & 2.16 & $\mathrm{a}$ \\
\hline SE & & \multicolumn{2}{|c|}{2} & \multicolumn{2}{|c|}{0} & \multicolumn{2}{|c|}{2} & \multicolumn{2}{|c|}{0.1} & \multicolumn{2}{|c|}{0.2} & \multicolumn{2}{|c|}{0.03} & \multicolumn{2}{|c|}{0.04} \\
\hline
\end{tabular}

${ }^{1}$ Abbreviations: POST, postemergence. ${ }^{2}$ Mineral oil/surfactant blend added at $0.5 \% \mathrm{v} / \mathrm{v} .{ }^{3}$ Mineral oil/surfactant blend added at $1.0 \% \mathrm{v} / \mathrm{v}$. ${ }^{4} \mathrm{Non}-\mathrm{ionic}$ surfactant added at $0.25 \% \mathrm{v} / \mathrm{v}$. ${ }^{5}$ Non-ionic surfactant added at $0.5 \% \mathrm{v} / \mathrm{v}$.

\subsection{Crop Injury}

The POST application of bentazon caused 5\% - 29\%, $4 \%-31 \%$, and $2 \%-18 \%$ injury, fomesafen caused $3 \%$ $17 \%, 1 \%-7 \%$, and $0 \%-6 \%$ injury, bentazon + fomesafen caused $6 \%-40 \%, 4 \%-37 \%$, and $1 \%-20 \%$ injury, and halosulfuron caused $13 \%-65 \%, 8 \%-75 \%$, and $5 \%$ $47 \%$ injury in mung bean at 1,2 , and 4 WAT, respectively (Table 1). Mung bean injury was significantly higher at Ridgetown compared to Exeter at all evaluation dates (Table 1). Injury was generally greater at the $2 \mathrm{X}$ rate compared to the $1 \mathrm{X}$ rate for each herbicide evaluated and decreased over time but differences were not always statistically significant (Table 2).
In other studies, less than 5\% injury was seen in various market classes of dry bean with fomesafen, bentazon + fomesafen and imazamox + fomesafen applied POST [10-12]. Wilson [13] found 3.5, 4.3, 4.8, and 6\% injury with fomesafen applied POST at 210, 280, 560, and $840 \mathrm{~g}$ a.i. ha ${ }^{-1}$ in dry bean, respectively. There was 8 and $6 \%$ injury when fomesfen + imazamox and fomesafen + bentazon were applied POST, respectively [13]. Injury up to $20 \%$ has been reported in snap bean with fomesafen applied POST at $280 \mathrm{~g}$ ai ha ${ }^{-1}$ [14]. Halosulfuron applied POST in other studies caused as much as $73 \%$ injury in adzuki bean and $13 \%$ injury in black, cranberry, kidney, otebo, pinto, small red Mexican and white beans [15]. Silvey et al. [16] reported 5\% injury from halosulfuron 
POST in snap bean (Phaseolus vulgaris L.). Van Gessel et al. [17] reported 0 to $33 \%$ injury to lima bean with imazamox + bentazon depending on site, year and application rate. Wall [18] found that thifensulfuron + bentazon applied POST caused $\leq 50 \%$ injury in navy bean at 2 WAT and $\leq 14 \%$ injury at 4 WAT. Stewart et al. [19] found up to $67 \%$ injury when halosulfuron was applied at $35 \mathrm{~g}$ ai ha ${ }^{-1}$ and $86 \%$ injury at $70 \mathrm{~g}^{\text {ai ha }}{ }^{-1}$ in adzuki bean.

\subsection{Shoot Dry Weight}

Fomesafen applied POST had no adverse effect on shoot dry weight of mung bean but bentazon, bentazon + fomesafen and halosulfuron applied POST decreased shoot dry weight of mung bean as much as 43,47 , and $57 \%$, respectively (Table 2 ).

In other studies, fomesafen applied alone had no adverse effect on the shoot dry weight of black, cranberry, kidney, and white bean [20]. The tank mix application of bentazon + fomesafen applied POST at $840+140$ or 1680 $+280 \mathrm{~g}$ a.i. $\mathrm{ha}^{-1}$ did not have any adverse effect on the shoot dry weight of black, brown, cranberry, kidney, otebo, pinto, white and yellow eye beans [12]. However, halosulfuron applied POST reduced shoot dry weight of adzuki bean $68 \%$, otebo bean $12 \%$, and small red Mexican bean $14 \%$ [15]. Shoot dry weight of black, cranberry, kidney, pinto and white beans was not affected with halosulfuron applied POST [15]. Stewart et al. [19] reported a significant reduction in shoot dry weight with halosulfuron and thifensulfuron applied POST in adzuki bean.

\subsection{Plant Height}

Plant height is important in mung bean production as shorter plants may have greater shatter loss at the cutter bar of combine during harvesting resulting in reduced harvested seed yield. At Exeter, fomesafen applied POST had no adverse effect on the height of mung bean (Table 2). However, bentazon, bentazon + fomesafen and halosulfuron applied POST decreased height of mung bean as much as $5 \%$ compared to the untreated control (Table 2). At Ridgetown, there was no decrease in the height of mung beans as a result of the herbicides applied compared to the untreated control (Table 2).

In other studies, bentazon + fomesafen applied POST reduced height of pinto beans $13 \%$ and white navy beans $9 \%$ at $1680+280 \mathrm{~g} \mathrm{ha}^{-1}$, however, there was no effect on height of black, brown, cranberry, kidney, otebo, and yellow eye bean [12]. Halosulfuron applied POST reduced adzuki bean height up to 60 and $70 \%$ at 35 and $70 \mathrm{~g}$ ai $\mathrm{ha}^{-1}$, respectively [15]. Thifensulfuron and halosulfuron also caused significant reduction in height of adzuki bean [19]. However, halosulfuron applied POST at 35 and 70 $\mathrm{g}$ ai ha ${ }^{-1}$ caused no adverse effect on the height of black, cranberry, kidney, otebo, pinto, small red Mexican and white beans [15].

\subsection{Seed Yield and Moisture Content}

Seed moisture content at harvest time is critical in dry bean production as low seed moisture (less than 13\%) can cause split seed coats and high seed moisture content (greater than 13\%) can increase respiration and deteriorate seed quality. Fomesafen, bentazon, bentazon + fomesafen and halosulfuron applied POST had no adverse effect on the seed moisture content of mung bean with the exception of halosulfuron applied POST at $70 \mathrm{~g}$ ai ha $^{-1}$ which increased seed moisture content $0.4 \%$ at Exeter and $1.4 \%$ at Ridgetown compared to the untreated control (Table 2). In other studies, halosulfuron applied POST increased seed moisture content $2.2 \%$ at $35 \mathrm{~g}$ ai ha ${ }^{-1}$ and $2.4 \%$ at $70 \mathrm{~g}$ ai ha ${ }^{-1}$ in adzuki bean and $3 \%$ in cranberry bean and $1.8 \%$ in kidney bean at $70 \mathrm{~g}$ ai ha ${ }^{-1}$ however, seed moisture content of black, otebo, pinto, small red Mexican and white beans was not affected with either rate of halosulfuron [15].

Fomesafen, bentazon, bentazon + fomesafen and halosulfuron applied POST had no adverse effect on the seed yield of mung bean with the exception of halosulfuron applied POST at $70 \mathrm{~g}$ ai ha ${ }^{-1}$ which decreased seed yield $16 \%$ at Exeter compared to the untreated control (Table 2). In other studies, fomesafen caused no adverse effect on seed yield of black, cranberry, kidney, and white bean [20]. The tank mix application of bentazon + fomesafen applied POST at $840+140$ or $1680+280 \mathrm{~g} \mathrm{ha}^{-1}$ has been shown to have no adverse effect on the seed yield of black, brown, cranberry, kidney, otebo, pinto, white and yellow eye beans [12]. Wilson [13] also reported no reduction in yield with fomesafen applied POST at 210 to $840 \mathrm{~g}^{\text {ai ha }}{ }^{-1}$ in dry bean. However, yield reductions of 0 to $22 \%$ have been reported with fomesafen in combination with imazamox when applied POST in white bean [10]. In other studies, halosulfuron applied POST decreased seed yield of adzuki bean up to $68 \%$ at $70 \mathrm{~g}$ ai ha ${ }^{-1}$, white bean up to $9 \%$ at $70 \mathrm{~g}$ ai ha ${ }^{-1}$ but had no adverse effect on black, cranberry, kidney, otebo, pinto and small red Mexican beans [15].

\section{CONCLUSION}

Bentazon, bentazon + fomesafen and halosulfuron applied POST at the proposed manufacturer's rate or twice that rate have potential to cause severe crop injury in mung beans. Fomesafen applied POST at the $1 \mathrm{X}$ rate caused initial injury in mung beans under some environments but the injury was minimal and transient with no adverse effect on plant height, biomass, seed moisture content, and seed yield. These results indicate that benta- 
zon, bentazon + fomesafen and halosulfuron applied POST do not have an adequate margin of crop safety for use in mung bean. However, fomesafen applied POST at the proposed manufacturer's rate of $240 \mathrm{~g}^{2} \mathrm{hi}^{-1}$ has potential for use in weed management in mung bean production. Further studies are needed to determine the efficacy of using fomesafen to control troublesome weeds in Ontario.

\section{ACKNOWLEDGEMENTS}

The authors would like to acknowledge Todd Cowan for his expertise and technical assistance in these studies. Funding for this project was provided in part by Ontario Bean Growers and the Agricultural Adaptation Council.

\section{REFERENCES}

[1] Guenther, L. (2012) Mung bean has potential for Western Canada.

http://saskpulse.com/news-events/news/mung-bean-has-p otential-for-western-canada/

[2] Arnold, N.R., Murray, W.M., Gregory, J.E. and Smeal, D. (1993) Weed control in pinto beans (Phaseolus vulgaris) with imazethapyr combinations. Weed Technology, 7, 361364.

[3] Malik, V.S., Swanton, C.J. and Michaels, T.E. (1993) Interaction of white bean (Phaseolus vulgaris) cultivars, row spacing, and seeding density with annual weeds. Weed Science, 41, 62-68.

[4] Chikoye, D., Weise, S.F. and Swanton, C.J. (1995) Influence of common ragweed (Ambrosia artemisiifolia) time of emergence and density on white bean (Phaseolus vulgaris). Weed Science, 43, 375-380.

[5] Burnside, O.C., Ahrens, W.H., Holder, B.J., Wiens, M.J., Johnson, M.M. and Ristau, E.A. (1994) Efficacy and economics of various mechanical plus chemical weed control systems in dry bean (Phaseolus vulgaris). Weed Technology, 8, 238-244.

[6] Bauer, T.A., Renner, K.A., Penner, D. and Kelly J.D. (1995) Pinto bean (Phaseolus vulgaris) varietal tolerance to imazethapyr. Weed Science, 43, 417-424.

[7] Urwin, C.P., Wilson, R.G. and Mortensen, D.A. (1996) Responses of dry edible bean (Phaseolus vulgaris) cultivars to four herbicides. Weed Technology, 10, 512-518.

[8] [OMAFRA] Ontario Ministry of Agriculture, Food, and Rural Affairs (2012) Guide to weed control. Publication 75. Ontario Ministry of Agriculture, Food, and Rural Affairs, Toronto.

[9] Senseman, S.A. (2007) Herbicide handbook. 9th Edition. Weed Science Society of America, Champaign, 458.
[10] Sikkema, P.H., Soltani, N., Shropshire, C. and Cowan, T. (2004) Tolerance of white beans to postemergence broadleaf herbicides. Weed Technology, 18, 893-901. http://dx.doi.org/10.1614/WT-03-043R3

[11] Soltani, N., Nurse, R.E., Robinson, D.E. and Sikkema, P.H. (2008) Response of pinto and Small Red Mexican bean to postemergence herbicides. Weed Technology, 22, 195-199. http://dx.doi.org/10.1614/WT-07-091.1

[12] Soltani, N., Shropshire, C. and Sikkema, P.H. (2006) Effects of post-emergence application of bentazon and fomesafen on eight market classes of dry beans (Phaseolus vulgaris L.). Crop Protection, 25, 826-830. http://dx.doi.org/10.1016/j.cropro.2005.11.011

[13] Wilson Jr., R.G. (2005) Response of dry bean and weeds to fomesafen tankmixtures. Weed Technology, 19, 201206. http://dx.doi.org/10.1614/WT-04-166R

[14] Bailey, W.A., Wilson, H.P. and Hines, T.E. (2003) Weed control and snap bean (Phaseolus vulgaris) response to reduced rates of fomesafen. Weed Technology, 17, 269275.

http://dx.doi.org/10.1614/0890-037X(2003)017[0269:WC ASBP]2.0.CO;2

[15] Soltani, N., Shropshire, C. and Sikkema, P.H. (2012) Response of dry bean to halosulfuron applied postemergence. Canadian Journal of Plant Science, 92, 723-728. http://dx.doi.org/10.4141/cjps2011-220

[16] Silvey, B.D., Mitchem, W.E., Macrae, A.W. and Monks, D.W. (2006) Snap bean (Phaseolus vulgaris) tolerance to halosulfuron PRE, POST, or PRE followed by POST. Weed Technology, 20, 873-876. http://dx.doi.org/10.1614/WT-05-046.1

[17] VanGessel, J.M., Monks, W.D. and Quintin, R.J. (2000) Herbicides for potential use in lima bean (Phaseolus lunatus) production. Weed Technology, 14, 279-286. http://dx.doi.org/10.1614/0890-037X(2000)014[0279:HF PUIL]2.0.CO;2

[18] Wall, D. (1995) Bentazon tank-mixtures for improved redroot pigweed (Amaranthus retroflexus) and common lambsquarters (Chenopodium album) control in navy bean (Phaseolus vulgaris). Weed Technology, 9, 610-616

[19] Stewart, C.L., Nurse, R.E., Gillard, C. and Sikkema, P.H. (2010) Tolerance of adzuki bean to preplant-incorporated, pre-emergence, and post-emergence herbicides in Ontario, Canada. Weed Biology and Management, 10, 40-47. http://dx.doi.org/10.1111/j.1445-6664.2010.00365.x

[20] Sikkema, P.H., Shropshire, C. and Soltani, N. (2009) Response of dry bean to pre-plant incorporated and preemergence applications of S-metolachlor and fomesafen. Crop Protection, 28, 744-748. http://dx.doi.org/10.1016/j.cropro.2009.05.011 